\title{
Effect of Molasses Addition at Ensiling on Ruminal In Situ Dry Matter and Nutrient Degradation of Whole-Plant Soybean Silage Harvested at Different Phenological Stages
}

\author{
Lucas Ghedin Ghizzi1 ${ }^{\circledR}$, Matheus Rebouças Pupo ${ }^{\circledR}{ }^{\circledR}$, Celso Heinzen Jr.2, \\ Tiago Antônio Del Valle ${ }^{3}$ (D), Francisco Palma Rennó ${ }^{\text {(D) }}$, Luiz Felipe Ferraretto ${ }^{* *}$ \\ ${ }^{1}$ Department of Animal Nutrition and Animal Production, University of Sao Paulo, Pirassununga, Brazil \\ ${ }^{2}$ Department of Animal and Dairy Sciences, University of Wisconsin, Madison, USA \\ ${ }^{3}$ Federal University of Santa Maria, Santa Maria, Brazil \\ Email: ^ferraretto@wisc.edu
}

How to cite this paper: Ghizzi, L.G., Pupo, M.R., Heinzen Jr., C., Del Valle, T.A., Rennó, F.P. and Ferraretto, L.F. (2022) Effect of Molasses Addition at Ensiling on Ruminal In Situ Dry Matter and Nutrient Degradation of Whole-Plant Soybean Silage Harvested at Different Phenological Stages. Agricultural Sciences, 13, 268-281.

https://doi.org/10.4236/as.2022.132018

Received: January 23, 2022

Accepted: February 22, 2022

Published: February 25, 2022

Copyright $\odot 2022$ by author(s) and Scientific Research Publishing Inc. This work is licensed under the Creative Commons Attribution International License (CC BY 4.0).

http://creativecommons.org/licenses/by/4.0/

\begin{abstract}
Whole-plant soybean ensiling has limitations and challenges that affect silage fermentation patterns and reduce ruminal nutrient degradation. Perhaps either the addition of molasses at ensiling or harvesting at different phenological stages has the potential to enhance whole-plant soybean silage (WSS) ruminal degradation. This experiment was a completely randomized design with a $3 \times 2$ factorial arrangement of treatments evaluating the effects of molasses ( 0 and $40 \mathrm{~g} / \mathrm{kg}$ fresh forage) and phenological stage (R5: beginning seed, R6: full seed, and R7: beginning maturity) on ruminal in situ degradation. Molasses increased effective ruminal degradability (ERD) of dry matter (DM) regardless of the phenological stage and increased ERD of crude protein at R5 and R6. The addition of molasses at later phenological stages increased ERD of neutral detergent fiber (NDF). There was a molasses $\times$ phenological stage interaction effect with greater fractions A and B of NDF at R7 and R5, respectively, but lower undegraded NDF at R5 and R6 with molasses addition. Although the benefits of adding molasses were more pronounced in R5 and R6, adding molasses to whole-plant soybean at ensiling is recommended regardless of phenological stage. Increasing the proportion of digestible nutrients at harvesting either by harvesting at later phenological stages or the addition of molasses is a powerful strategy to manage ruminal degradation of DM and nutrients in WSS.
\end{abstract}

Keywords

Additive, In Situ Degradation, Ruminal Degradation Parameters, Legume 
Ensiling

\section{Introduction}

Utilizing homegrown forages with a high protein concentration increases the cost-effectiveness and sustainability of high-producing livestock systems. Previous studies highlighted the significant potential, but inconsistent results of whole-plant soybean silage (WSS) for ruminant nutrition [1] [2] [3]. Nevertheless, whole-plant soybean fermentation has limitations and challenges, such as low water-soluble carbohydrates (WSC) and dry matter (DM) concentrations, as well as high buffering capacity [4]. These characteristics impair silage fermentation by promoting proteolysis, and thereby, the production of poor-quality silage with high $\mathrm{pH}$, ammonia-nitrogen $\left(\mathrm{NH}_{3}-\mathrm{N}\right)$, and butyric acid concentrations [5], leading to decreased ruminal nutrient degradation [6] [7].

Molasses is an additive with the potential to enhance WSS fermentation and ruminal degradation by increasing the availability of fermentable substrate to lactic acid bacteria. The addition of molasses $(20 \mathrm{~g} / \mathrm{kg}$ fresh forage) increased lactic acid concentration and reduced WSS pH [4]. Research literature [6] evaluating increasing doses of molasses $(0,30,60$, and $90 \mathrm{~g} / \mathrm{kg}$ fresh forage) on WSS, observed a proportional increase of DM and lactic acid concentrations as well as a decrease of $\mathrm{pH}, \mathrm{NH}_{3}-\mathrm{N}$, and butyric acid concentrations in WSS, suggesting a dose-dependent response. Furthermore, greater ruminal degradation of $\mathrm{DM}$, crude protein $(\mathrm{CP})$, neutral detergent fiber inclusive of residual ash (NDF), and non-fiber carbohydrates (NFC) were observed in beef cattle diets containing WSS with molasses addition [7]. Improvements in fermentation profile reduce losses of neutral detergent solubles, which are more digestible than cell wall constituents [5], increasing ruminal degradability.

Moreover, the phenological stage at harvest influences the nutritive value of WSS mainly due to an increase in the proportion of pods and decrease in the proportion of leaves with later phenological stage [8]. These changes could affect the concentrations of digestible and indigestible fractions of WSS. A linear decline in dry matter intake and milk yield, with no effect on milk fat concentration was observed when $50 \%$ of forage DM (corn silage) was replaced with WSS harvested at 50\% of full seed stage (R5.5) [3]. These responses were associated with impaired WSS fermentation and increased concentration of indigestible $\mathrm{NDF}$ as diets were formulated to be isonitrogenous and isoenergetic. Likewise, there was a decrease of soluble fractions and effective ruminal degradability (ERD) of DM and CP for WSS ensiled at beginning maturity (R7) compared to full seed (R6) stage [9]. A wide range of phenological stages from beginning seed (R5) to R7 has been commonly used to define when to begin harvesting WSS [10]. However, which phenological stage supports the greater nutrient degradation in the rumen is still unknown. 
The effect of molasses to stimulate fermentation and increase nutrient availability in different phenological stages is not extensively investigated in the literature. We hypothesized that molasses would improve ruminal degradation of DM, CP, and NDF regardless of the phenological stage at harvest. Thus, the objective of this retrospective study was to evaluate the effects of molasses on ruminal DM, CP, and NDF degradation parameters, ERD, and undegraded neutral detergent fiber (uNDF; NDF basis) concentration of WSS harvested at R5, R6, and R7 phenological stages.

\section{Material and Methods}

\subsection{Crop Establishment, Harvesting, and Ensiling}

The first phase of the experiment (original study) [11] was carried out at the Dairy Cattle Research Laboratory of the University of São Paulo (LPBL/USP, Pirassununga, Brazil), and the second phase (current retrospective study) was performed at the Dairy Research Unit and Department of Animal Sciences of University of Florida (DRU/UF, Gainesville, FL, USA).

Soybean (Glycine max cultivar Agroeste ${ }^{\circledR} 3610$ I PRO, Xanxerê, Brazil) was seeded in an experimental field localized $21^{\circ} 58^{\prime} 19.8^{\prime \prime}$ south and $47^{\circ} 28^{\prime} 15.9^{\prime \prime}$ west, at $620 \mathrm{~m}$ of altitude, subtropical humid (Cwa), and $1200 \mathrm{~mm}$ of mean annual rainfall. Soybean plants were harvested at three different phenological stages (R5: beginning seed, R6: full seed, and R7: beginning maturity [12] at 90, 113, and 124 days after seeded respectively). For each stage, $30 \mathrm{~kg}$ of forage material was harvested from each of five different plots previously determined in the field, hand-mixed to get a composite sample of $150 \mathrm{~kg}$ of fresh forage for each stage and was chopped (Cremasco ${ }^{\circledR}$ ECT-4000) targeting $20 \mathrm{~mm}$ of the theoretical length of cut. Fresh forage samples of each plot and phenological stage were collected for nutrient characterization.

A dose of $40 \mathrm{~g} / \mathrm{kg}$ fresh forage of molasses was top-dressed on $2400 \mathrm{~g}$ of the composite sample and hand-mixed before placing into experimental silos, while the control group was not treated with molasses. The experimental silos (10 silos/treatment - 60 in total; silos were not used as experimental units in the current retrospective study) were made with polyvinyl chloride pipe with $0.5 \mathrm{~m}$ height and $0.1 \mathrm{~m}$ i.d. to achieve $650 \mathrm{~kg} / \mathrm{m}^{3}$ fresh forage. All silos were sealed with plastic canvas (sailcloth $200 \mu \mathrm{m}$; Superlona black/white, Electro Plastic, Varginha, Brazil), taped within $2 \mathrm{~h}$ after harvest, and stored for $90 \mathrm{~d}$.

\subsection{Chemical Analysis of Whole-Plant Soybean Fresh Forage}

For chemical profile characterization, fresh forage samples were individually dried at $55^{\circ} \mathrm{C}$ for $72 \mathrm{~h}$ in a forced-air oven and ground to pass through a $1-\mathrm{mm}$ sieve. The 1-mm ground samples were analyzed for absolute DM (method 950.15; correction of $\mathrm{DM}$ at $\left.105^{\circ} \mathrm{C}\right)$ [13], $\mathrm{CP}(\mathrm{N} \times 6.25$; Kjeldahl method 984.13) [14], ether extract (EE; method 920.39) [14], NDF, acid detergent fiber (ADF), and lignin (sulfuric acid method) concentrations by sequential analysis [15] us- 
ing a heat stable $\alpha$-amylase [16] and sodium sulfite (TE-149 fiber analyzer, Tecnal Laboratory Equipment Inc., Piracicaba, Brazil). Non-fiber carbohydrate $(\mathrm{NFC})$ concentration was calculated as $\mathrm{NFC}=1000-(\mathrm{NDF}+\mathrm{CP}+\mathrm{EE}+$ ash $)$ [17].

Chemical composition of whole-plant soybean fresh forage (average weight $\mathrm{g} / \mathrm{kg} \mathrm{DM}$ ) is in Table 1. As expected, concentration of DM increased from 253 to $353 \mathrm{~g} / \mathrm{kg} \mathrm{DM}$, as phenological stage progressed. Organic matter concentration ranged from 925 to $937 \mathrm{~g} / \mathrm{kg} \mathrm{DM}$, as was very similar among phenological stages. Concentration of NDF and ADF decreased from 610 to 541 and 462 to $415 \mathrm{~g} / \mathrm{kg}$ $\mathrm{DM}$, respectively, as phenological stage progressed from R5 to R7. In addition, $\mathrm{CP}$ and $\mathrm{EE}$ concentrations increased with phenological stage.

\subsection{Chemical Analysis of Whole-Plant Soybean Silage}

At opening, the top $10 \mathrm{~cm}$ of WSS was discarded from each experimental silo and the remaining sample was homogenized for further analysis. For fermentation profile characterization, $15 \mathrm{~g}$ from each experimental silo was mixed with $250 \mathrm{~mL}$ of distilled water for $30 \mathrm{~s}$ and the silage juice was evaluated for $\mathrm{pH}$ and buffering capacity [18] using a pH meter (MB-10, Marte Cientifica ${ }^{\circledR}$, Santa Rita do Sapucaí, Brazil). Silage juice was centrifuged $(2000 \times \mathrm{g}$ for $15 \mathrm{~min}$.), and the supernatant aliquot $(0.9 \mathrm{~mL})$ was mixed $(1: 1)$ with $450 \mu \mathrm{L}$ sulfuric acid $(1 \mathrm{~N})$, for ammonia nitrogen $\left(\mathrm{NH}_{3}-\mathrm{N}\right)$ concentration analysis by colorimetric phenol-hypochlorite method [19]. For lactic acid concentration, a supernatant aliquot $(1 \mathrm{~mL})$ was frozen until further analysis [20]. For the concentration of organic acids, a supernatant aliquot $(1.6 \mathrm{~mL})$ of silage juice was mixed (4:1) with $0.4 \mathrm{~mL}$ ortho-fosforic acid (20\%) and frozen until analysis. Briefly, organic acids were determined using a gas chromatograph equipment (GC-2014 Plus, Shimadzu $\odot$, Kyoto, Japan) equipped with automatic injector $\left(\mathrm{AOC}-20 \mathrm{i}\right.$ at $\left.300^{\circ} \mathrm{C}\right)$, capillary column (Stabilwax-DA ${ }^{\mathrm{mm}}$ : $30 \mathrm{~m}$ length, and $0.25 \mathrm{~mm}$ i.d.; Restek ${ }^{\odot}$,

Table 1. Chemical composition of whole-plant soybean (mean \pm standard deviation $\mathrm{g} / \mathrm{kg}$ $\mathrm{DM})$.

\begin{tabular}{ccccc}
\hline \multirow{2}{*}{ Item } & \multicolumn{3}{c}{ Phenological stage $^{1}$} & \multirow{2}{*}{ Molasses } \\
\cline { 2 - 4 } & R5 & R6 & R7 & \\
\hline Dry matter & $253 \pm 7.08$ & $292 \pm 3.20$ & $353 \pm 3.05$ & 960 \\
Organic matter & $925 \pm 1.58$ & $935 \pm 1.30$ & $937 \pm 1.09$ & 828 \\
Neutral detergent fiber & $610 \pm 21.2$ & $585 \pm 10.1$ & $541 \pm 7.49$ & 65.6 \\
Acid detergent fiber & $462 \pm 18.5$ & $424 \pm 8.95$ & $415 \pm 13.4$ & 25.8 \\
Crude protein & $192 \pm 7.81$ & $198 \pm 4.98$ & $215 \pm 8.19$ & 32.5 \\
Non fiber carbohydrates & $108 \pm 11.9$ & $109 \pm 9.24$ & $104 \pm 7.68$ & 730 \\
Ether extract & $14 \pm 1.41$ & $42 \pm 1.79$ & $77 \pm 4.25$ & $\mathrm{nd}^{*}$ \\
\hline
\end{tabular}

${ }^{1}$ R5: beginning seed; R6: full seed; R7: beginning maturity; ${ }^{\star}$ not detected. 
Bellefonte, USA) and flame ionization detector using helium as the carrier gas with a linear speed of $42 \mathrm{~cm}^{3} / \mathrm{s}$. The temperature ramp of the column started with a gradient from $40^{\circ} \mathrm{C}$ to $120^{\circ} \mathrm{C}$, at a rate of $40^{\circ} \mathrm{C} / \mathrm{min}$, followed by ranges of $120^{\circ} \mathrm{C}$ to $180^{\circ} \mathrm{C}$, at $10^{\circ} \mathrm{C} / \mathrm{min}$, and from $180^{\circ} \mathrm{C}$ to $240^{\circ} \mathrm{C}$, at $120^{\circ} \mathrm{C} / \mathrm{min}$, holding temperature at $240^{\circ} \mathrm{C}$ for $3 \mathrm{~min}$ at the end of analysis. Data were analyzed using the GCsolution software (v.2.42.00; Shimadzu Corporation, Kyoto, Japan).

Remaining samples from each experimental silo were dried at $55^{\circ} \mathrm{C}$ for $72 \mathrm{~h}$ in a forced-air oven and ground to pass through a $2-\mathrm{mm}$ sieve and were composited per treatment ( 6 samples in total, 1 for each treatment used in the present trial) for the DM, CP, and NDF in situ degradability assays. Composited 2-mm ground samples were ground to pass through a 1-mm sieve and analyzed for DM (method 950.15) [13], CP [N $\times 6.25$; total $\mathrm{N}$ was analyzed by the Dumas dry combustion method (method 968.06) [13] using a CHNS analyzer (Vario Micro Cube; Elementar, Hanau, Germany)], and NDF (method 2002.04) [13] in an ANKOM 200 Fiber Analyzer (Ankom Technologies, Macedon, NY).

The addition of molasses slightly altered chemical concentrations of DM, NDF, CP, and lignin throughout the late compared to early phenological stages, whereas greatly changes were observed for fermentation parameters regardless of the phenological stage (Table 2).

\subsection{In Situ Assays}

Ruminal in situ procedures were conducted at the University of Florida (Gainesville, FL) under a protocol approved by the University of Florida, Institute of

Table 2. Chemical composition and fermentation profile (mean \pm standard deviation) of whole-plant soybean silage harvested at different phenological stages, with or without the addition of molasses. $(n=10)$.

\begin{tabular}{ccccccc}
\hline \multirow{2}{*}{ Item } & \multicolumn{2}{c}{ R5 $^{1}$} & \multicolumn{2}{c}{ R6 $^{2}$} & R7 $^{3}$ \\
\cline { 2 - 6 } & Control $^{4}$ & Molasses $^{5}$ & Control & Molasses & Control & Molasses $^{2}$ \\
\hline DM $^{6}$, g/kg fresh forage & $203 \pm 4.74$ & $238 \pm 5.82$ & $248 \pm 3.87$ & $287 \pm 7.24$ & $318 \pm 5.54$ & $343 \pm 10.3$ \\
NDF, g/kg DM & $625 \pm 22.5$ & $515 \pm 22.0$ & $588 \pm 15.8$ & $513 \pm 11.2$ & $551 \pm 13.0$ & $510 \pm 22.9$ \\
CP $^{8}$, g/kg DM & $123 \pm 10.8$ & $175 \pm 12.2$ & $184 \pm 9.48$ & $189 \pm 7.45$ & $224 \pm 11.0$ & $204 \pm 12.0$ \\
Lignin, g/kg DM & $132 \pm 6.69$ & $94.6 \pm 9.14$ & $118 \pm 6.98$ & $97.2 \pm 6.52$ & $89.7 \pm 9.38$ & $86.2 \pm 7.88$ \\
Acetic acid, g/kg DM & $78.7 \pm 6.36$ & $40.2 \pm 8.25$ & $31.3 \pm 6.65$ & $14.3 \pm 3.60$ & $32.2 \pm 2.40$ & $15.0 \pm 2.34$ \\
Butyric acid, g/kg DM & $39.3 \pm 4.88$ & $13.3 \pm 20.6$ & $43.9 \pm 10.5$ & $45.8 \pm 19.1$ & $21.1 \pm 6.18$ & $25.2 \pm 11.8$ \\
Propionic acid, g/kg DM & $16.4 \pm 1.75$ & $5.29 \pm 1.48$ & $29.5 \pm 2.33$ & $8.41 \pm 2.00$ & $20.1 \pm 3.02$ & $5.20 \pm 1.26$ \\
Lactic acid, g/kg DM & $4.36 \pm 1.06$ & $7.82 \pm 1.97$ & $2.49 \pm 0.766$ & $4.22 \pm 1.42$ & $4.36 \pm 1.59$ & $1.86 \pm 0.280$ \\
NH -N, g/kg DM & $32.9 \pm 5.71$ & $23.7 \pm 6.09$ & $20.0 \pm 4.28$ & $16.3 \pm 4.04$ & $13.4 \pm 3.51$ & $15.1 \pm 2.45$ \\
pH & $5.81 \pm 0.074$ & $4.98 \pm 0.204$ & $5.98 \pm 0.227$ & $5.68 \pm 0.345$ & $5.80 \pm 0.165$ & $5.39 \pm 0.314$ \\
Buffering capacity & $10.1 \pm 0.527$ & $7.29 \pm 0.734$ & $6.06 \pm 0.419$ & $4.63 \pm 0.332$ & $4.92 \pm 0.186$ & $3.90 \pm 0.156$ \\
\hline
\end{tabular}

${ }^{1}$ R5: beginning seed. ${ }^{2}$ R6: full seed. ${ }^{3}$ R7: beginning maturity. ${ }^{4}$ Control: no additive. ${ }^{5}$ Molasses: $40 \mathrm{~g} / \mathrm{kg}$ fresh forage. ${ }^{6} \mathrm{Dry}$ matter. ${ }^{7}$ Neutral detergent fiber. ${ }^{8}$ Crude protein. ${ }^{9}$ meq. of alkali required of changing the $\mathrm{pH}$ from 4 to 6 per $100 \mathrm{~g}$ of dry matter [18]. 
Food and Agricultural Sciences, and Animal Care Research Committee (protocol \#201709849). A completely randomized design with a $3 \times 2$ factorial arrangement of treatments was used considering phenological stage (R5, R6, and R7) and the addition of molasses ( 0 and $40 \mathrm{~g} / \mathrm{kg}$ fresh forage) as main effects and rumen environment (cow) as experimental units. Ruminal in situ measurements were performed using three rumen-cannulated, mid-lactation, multiparous Holstein cows fed ad libitum a diet containing (DM basis) corn silage $(382 \mathrm{~g} / \mathrm{kg}$ ), alfalfa hay $(40 \mathrm{~g} / \mathrm{kg})$, dry ground shelled corn $(273 \mathrm{~g} / \mathrm{kg})$, soybean meal (145 $\mathrm{g} / \mathrm{kg}$ ), citrus pulp $(91 \mathrm{~g} / \mathrm{kg})$, minerals and supplements $(68 \mathrm{~g} / \mathrm{kg})$. Cows were consuming this diet for at least $21 \mathrm{~d}$ prior to the experiment.

Dacron polyester cloth bags (R1020, $10 \times 20 \mathrm{~cm}$ and $50 \pm 10 \mu \mathrm{m}$ pores; Ankom Technology, Macedon, NY, USA) containing $5 \mathrm{~g}$ of dried and 2-mm ground composited WSS samples (6 samples in total, 1 for each treatment), yielding a ratio of sample mass to bag area of $16.6 \mathrm{mg} / \mathrm{cm}^{2}$ were incubated in duplicate within each cow. A total of 96 bags were incubated within each cow (6 treatments in duplicated for each of the 8 time-points). Average of duplicated bags of each treatment generated the kinetic parameter estimates on each rumen environment (cow).

Bags were placed in a nylon laundry bag $(30 \times 40 \mathrm{~cm})$ and incubated in the ventral rumen of each cow in reverse chronological order for $240,120,72,48,24$, 12,6 , and $3 \mathrm{~h}$. Additionally, two empty bags for each time point (16 bags in to$\mathrm{tal} / \mathrm{cow}$ ) were incubated to correct bag infiltration or losses. After the incubation period, bags were removed from the rumen, soaked in cold water to stop fermentation, and rinsed in a washing machine using the mode rinse and spin cycle, set with room temperature water for a 30-min cycle (Roper RTW4516F*, Whirlpool Corp., Benton Harbor, MI). Each treatment had two bags prepared, soaked, and washed together with the rest of in situ bags ( $0 \mathrm{~h}$ bags). After washing, bags were dried in a forced-air oven at $60^{\circ} \mathrm{C}$ for $48 \mathrm{~h}$, and the difference between the initial and final DM amount was considered as DM disappearance. Rumen incubated residues from duplicates within each treatment, timepoint and cow were composited, ground to pass through a $1-\mathrm{mm}$ Wiley mill screen, and analyzed for $\mathrm{CP}(0,3,6,12,24,48$, and $72 \mathrm{~h})$ and $\operatorname{NDF}(0,3,6,12,24,48,72$, 120 , and $240 \mathrm{~h}$ ) concentrations as previously described (method 968.06 [16] and method 2002.04 [16], respectively). The NDF residue at $240 \mathrm{~h}$ was considered as uNDF concentration (DM basis).

The degradation of DM, CP and, NDF were calculated without correction for microbial protein contamination and calculated by the exponential model according to the Equation (1) [21], and the parameters estimated by PROC NLIN of SAS (version 9.3, SAS Institute Inc., Cary, NC, USA) as follows:

$$
D_{t}=A+B \times\left(1-\exp ^{-k_{d} \times t}\right),
$$

where $D_{t}$ is degradation (\% DM) at time $t, A$ is an intercept representing the proportion of soluble fraction (\% DM); $B$ is the insoluble but potentially rumen 
degradable fraction (\% DM); $k_{d}$ is the fractional rate of soluble degradation of the fraction $B(h) ; t$ is the incubation time $(h)$.

The effective ruminal degradability (ERD) of DM, CP, and NDF were calculated according to the Equation (2) [21],

$$
E R D=A+B \times\left(\frac{k_{d}}{k_{d}+k_{p}}\right)
$$

where $A, B$, and $k_{d}$ are the same parameters as described earlier, and $k_{p}$ is a passage rate set to $3 \% / \mathrm{h}[21]$.

\subsection{Statistical Analysis}

Data on fractions $\mathrm{A}, \mathrm{B}$, and $\mathrm{C}, k_{d}, \mathrm{ERD}, D_{t}$, and uNDF concentration were analyzed as a completely randomized block design with the three cows designated as blocks. Average of duplicated bags of each treatment that generated the kinetic parameter estimates on each block (cow) were the experimental units. Analysis was performed by a mixed model procedure (PROC MIXED in SAS; SAS Institute Inc., Cary, NC, United States) according to the following model:

$$
Y_{i j k}=\mu+S_{i}+M_{j}+c_{k}+S M_{i j}+e_{i j k},
$$

with $c_{k} \approx N\left(0, \sigma_{c k}^{2}\right)$ and $e_{i j k} \approx N\left(0, \sigma_{e}^{2}\right)$; where $Y_{i j k}$ is the value of the dependent variable, $\mu$ is the overall mean, $S_{i}$ is the fixed effect of the phenological stage ( $i=1$ to 3 ), $M_{j}$ is the fixed effect of molasses $(j=1$ and 2$), c_{k}$ is the random effect of cow ( $k=1$ to 3$), S M_{i j}$ is the fixed interaction effect, and $e_{i j k}$ is the residual error. $N$ stands Gaussian distribution, $\sigma_{e}^{2}$ is the residual variance, and $\sigma_{c k}^{2}$ is the variance associated with the random effect of cow. Degrees of freedom were adjusted based on Kenward-Roger's method, an approach specifically proposed for small sample setting as a precaution for inflated error variance [22]. Significance was declared at $\mathrm{P} \leq 0.05$.

\section{Results}

\subsection{Dry Matter Kinetic Parameters}

Molasses did not affect $(P \geq 0.15)$ fraction $B$ or the $k_{d}$ of $D M$, but both were greater $(\mathrm{P}=0.001)$ at $\mathrm{R} 7$ compared to earlier phenological stages (Table 3$)$. A molasses by phenological stage interaction was detected $(P \leq 0.03)$ on fractions $A$ and $C$, and ERD of DM. Addition of molasses increased $(P \leq 0.05)$ fraction $A$ regardless of phenological stage, but differences among phenological stages were only observed when WSS was not treated with molasses. Molasses addition increased $(P \leq 0.05)$ ERD while decreasing $(P \leq 0.05)$ fraction $C$ of $D M$ at $R 5$ and R6, but not R7 phenological stage.

\subsection{Crude Protein Kinetic Parameters}

Molasses enhanced $(\mathrm{P} \leq 0.05)$ the ERD of $\mathrm{CP}$ at R5 and R6, but not at R7 (Table 4). The addition of molasses increased $(\mathrm{P}=0.01)$ fraction $\mathrm{A}$ and decreased $(\mathrm{P}=$ 
Table 3. Effects of molasses and phenological stage on ruminal DM degradation kinetic parameters and effective ruminal degradability of whole-plant soybean silage (\% DM, unless otherwise stated).

\begin{tabular}{|c|c|c|c|c|c|c|c|c|c|c|}
\hline \multirow{2}{*}{ Parameters $^{1}$} & \multicolumn{3}{|c|}{ Control $^{2}$} & \multicolumn{3}{|c|}{ Molasses $^{3}$} & \multirow{2}{*}{ SEM } & \multicolumn{3}{|c|}{ P-value ${ }^{7}$} \\
\hline & $\mathrm{R}^{4}$ & $R 6^{5}$ & $\mathrm{R}^{6}$ & R5 & R6 & R7 & & MOL & PS & INT \\
\hline A & $31.7^{c}$ & $33.8^{\mathrm{bc}}$ & $34.3^{\mathrm{b}}$ & $40.6^{\mathrm{a}}$ & $39.6^{\mathrm{a}}$ & $39.0^{\mathrm{a}}$ & 0.96 & 0.001 & 0.001 & 0.03 \\
\hline B & 31.3 & 32.5 & 36.9 & 30.0 & 33.6 & 33.1 & 1.19 & 0.15 & 0.001 & 0.28 \\
\hline $\mathrm{C}$ & $36.9^{\mathrm{a}}$ & $33.6^{\mathrm{b}}$ & $28.8^{\mathrm{cd}}$ & $29.4^{c}$ & $26.8^{\mathrm{d}}$ & $27.9^{\mathrm{cd}}$ & 0.94 & 0.001 & 0.03 & 0.001 \\
\hline $\mathrm{kd}, \% \mathrm{~h}^{-1}$ & 0.047 & 0.051 & 0.064 & 0.053 & 0.049 & 0.058 & 0.0057 & 0.83 & 0.001 & 0.22 \\
\hline ERD & $50.8^{c}$ & $54.3^{\mathrm{b}}$ & $59.5^{\mathrm{a}}$ & $59.7^{\mathrm{a}}$ & $60.4^{\mathrm{a}}$ & $60.8^{\mathrm{a}}$ & 0.48 & 0.001 & 0.001 & 0.001 \\
\hline
\end{tabular}

${ }^{1} \mathrm{~A}: \mathrm{r}^{\mathrm{a}-\mathrm{c}}$ Means in the same row with different superscripts differ $(\mathrm{P}<0.05)$. uminal rapidly degradable fraction; $\mathrm{B}$ : ruminal slowly degradable fraction; C: ruminal indigestible fraction; kd: degradation rate constant of fraction B; ERD: effective ruminal degradability at ruminal passage rate of $0.03 \mathrm{~h}^{-1}$ by Ørskov and McDonald [21]. ${ }^{2}$ Control: no additive; ${ }^{3}$ Molasses: $40 \mathrm{~g} / \mathrm{kg}$ as-fed forage. ${ }^{4} \mathrm{R} 5$ : beginning seed; ${ }^{5}$ R6: full seed; ${ }^{6} \mathrm{R} 7$ : beginning maturity. ${ }^{7} \mathrm{MOL}$ : molasses, PS: phenological stage, and INT: molasses and phenological stage interaction effects.

Table 4. Effects of molasses and phenological stage on ruminal CP degradation kinetic parameters and effective ruminal degradability of whole-plant soybean silage (\% CP, unless otherwise stated).

\begin{tabular}{|c|c|c|c|c|c|c|c|c|c|c|}
\hline \multirow{2}{*}{ Parameters $^{1}$} & \multicolumn{3}{|c|}{ Control $^{2}$} & \multicolumn{3}{|c|}{ Molasses $^{3}$} & \multirow{2}{*}{ SEM } & \multicolumn{3}{|c|}{$P$-value ${ }^{7}$} \\
\hline & $\mathrm{R} 5^{4}$ & $R 6^{5}$ & $\mathrm{R}^{6}$ & R5 & R6 & R7 & & MOL & PS & INT \\
\hline A & 64.4 & 58.5 & 57.0 & 67.0 & 64.5 & 59.1 & 1.72 & 0.01 & 0.001 & 0.88 \\
\hline $\mathrm{B}$ & 34.3 & 31.6 & 38.3 & 26.4 & 31.5 & 33.5 & 2.43 & 0.01 & 0.001 & 0.44 \\
\hline $\mathrm{C}$ & 1.31 & 9.80 & 4.75 & 6.63 & 3.96 & 7.36 & 2.49 & 0.66 & 0.18 & 0.42 \\
\hline $\mathrm{k}_{\mathrm{d}}, \% \mathrm{~h}^{-1}$ & 0.018 & 0.041 & 0.064 & 0.047 & 0.033 & 0.062 & 0.0118 & 0.43 & 0.01 & 0.11 \\
\hline ERD & $77.4^{\mathrm{b}}$ & $76.9^{\mathrm{b}}$ & $83.1^{\mathrm{a}}$ & $83.1^{\mathrm{a}}$ & $81.0^{\mathrm{a}}$ & $81.8^{\mathrm{a}}$ & 0.86 & 0.001 & 0.001 & 0.001 \\
\hline
\end{tabular}

${ }^{\mathrm{a}-\mathrm{b}}$ Means in the same row with different superscripts differ $(\mathrm{P}<0.05) .{ }^{1} \mathrm{~A}$ : ruminal rapidly degradable fraction; B: ruminal slowly degradable fraction; C: ruminal indigestible fraction; $k d$ : degradation rate constant of fraction B; ERD: effective ruminal degradability at ruminal passage rate of $0.03 \mathrm{~h}^{-1}$ by Ørskov and McDonald [21]. ${ }^{2}$ Control: no additive; ${ }^{3}$ Molasses: $40 \mathrm{~g} / \mathrm{kg}$ of as-fed forage. ${ }^{4}$ R5: beginning seed; ${ }^{5}$ R6: full seed; ${ }^{6}$ R7: beginning maturity. ${ }^{7} \mathrm{MOL}$ : molasses, PS: phenological stage, and INT: molasses and phenological stage interaction effects.

0.01) fraction $B$, with no differences $(P \geq 0.43)$ on fraction $C$ or the $k_{d}$ of $C P$. Later phenological stages decreased $(\mathrm{P}=0.001)$ fraction $\mathrm{A}$ and increased $(\mathrm{P} \leq$ $0.01)$ fraction $B$ and $k_{d}$, with no effect $(P=0.18)$ on fraction $C$ of $C P$. There were no interaction effects $(P \geq 0.11)$ on fractions $A, B, C$, or $k_{d}$ of CP.

\subsection{Neutral Detergent Fiber Kinetic Parameters}

The addition of molasses decreased $(P=0.01)$ fraction $C$, increased $(P=0.001)$ ERD, and had no effect $(\mathrm{P}=0.51)$ on the $\mathrm{k}_{\mathrm{d}}$ of NDF (Table 5). Harvesting WSS at a later phenological stage decreased $(P=0.001)$ fraction $C$ and $k_{d}$, increasing $(\mathrm{P}=0.001)$ the ERD of NDF. Moreover, an interaction between the addition of molasses and phenological stage was detected $(\mathrm{P} \leq 0.04)$ on fractions $\mathrm{A}$ and $\mathrm{B}$ of NDF, and uNDF. Fractions $A$ and $B$ of NDF were greater $(P \leq 0.05)$ at R7 and 
Table 5. Effects of molasses and phenological stage on ruminal NDF degradation kinetic parameters and effective ruminal degradability of whole-plant soybean silage (\% NDF, unless otherwise stated).

\begin{tabular}{|c|c|c|c|c|c|c|c|c|c|c|}
\hline \multirow{2}{*}{ Parameters $^{1}$} & \multicolumn{3}{|c|}{ Control $^{2}$} & \multicolumn{3}{|c|}{ Molasses $^{3}$} & \multirow{2}{*}{ SEM } & \multicolumn{3}{|c|}{$P$-value ${ }^{7}$} \\
\hline & $\mathrm{R} 5^{4}$ & $R 6^{5}$ & $\mathrm{R} 7^{6}$ & R5 & $\mathrm{R} 6$ & R7 & & MOL & PS & INT \\
\hline A & $5.35^{c}$ & $9.17^{\mathrm{b}}$ & $10.4^{\mathrm{b}}$ & $3.30^{c}$ & $10.7^{\mathrm{ab}}$ & $13.6^{\mathrm{a}}$ & 1.08 & 0.32 & 0.001 & 0.02 \\
\hline B & $31.3^{\mathrm{b}}$ & $32.2^{\mathrm{ab}}$ & $33.4^{\mathrm{ab}}$ & $35.9^{\mathrm{a}}$ & $35.8^{\mathrm{a}}$ & $31.9^{\mathrm{ab}}$ & 1.63 & 0.07 & 0.001 & 0.04 \\
\hline $\mathrm{C}$ & 63.3 & 58.6 & 56.1 & 60.8 & 53.6 & 54.5 & 1.48 & 0.01 & 0.001 & 0.71 \\
\hline $\mathrm{k}_{\mathrm{d}}, \% \mathrm{~h}^{-1}$ & 0.046 & 0.039 & 0.043 & 0.043 & 0.042 & 0.034 & 0.0052 & 0.51 & 0.001 & 0.51 \\
\hline ERD & 24.2 & 27.3 & 30.0 & 24.5 & 31.4 & 30.6 & 0.596 & 0.001 & 0.001 & 0.86 \\
\hline uNDF & $71.5^{\mathrm{d}}$ & $63.0^{c}$ & $58.3^{\mathrm{b}}$ & $61.5^{c}$ & $54.3^{\mathrm{a}}$ & $58.6^{\mathrm{b}}$ & 0.98 & 0.001 & 0.001 & 0.01 \\
\hline
\end{tabular}

${ }^{\mathrm{a}-\mathrm{d}}$ Means in the same row with different superscripts differ $(\mathrm{P}<0.05) .{ }^{1} \mathrm{~A}$ : ruminal rapidly degradable fraction; B: ruminal slowly degradable fraction; C: ruminal indigestible fraction; $\mathrm{kd}$ : degradation rate constant of fraction $\mathrm{B}$; ERD: effective ruminal degradability at ruminal passage rate of $0.03 \mathrm{~h}^{-1}$; undegraded $\mathrm{NDF}$ at $240 \mathrm{~h}$ of ruminal incubation $(\mathrm{g} / \mathrm{kg} \mathrm{DM})$ by Ørskov and McDonald [21]. ${ }^{2}$ Control: no additive; ${ }^{3}$ Molasses: $40 \mathrm{~g} / \mathrm{kg}$ of as-fed forage. ${ }^{4} \mathrm{R} 5$ : beginning seed; ${ }^{5} \mathrm{R} 6$ : full seed; ${ }^{6} \mathrm{R}$ : beginning maturity. ${ }^{7} \mathrm{MOL}$ : molasses, PS: phenological stage, and INT: molasses and phenological stage interaction effects.

$R 5$, respectively, while uNDF was decreased $(\mathrm{P} \leq 0.05)$ at $\mathrm{R} 5$ and $\mathrm{R} 6$ when silages were treated with molasses.

\subsection{Degraded Dry Matter, Neutral Detergent Fiber, and Crude Protein}

Degraded DM, NDF, and CP concentrations in WSS at each incubation timepoint are presented in Figure 1.

\section{Discussion}

A positive effect of phenological stage was observed on ruminal degradation parameters of DM, CP, and NDF. However, the magnitude of these effects was lower in molasses-treated silages. The reason for that is related to the chemical composition of soybean plant in late stages which is closer to ideal for a good fermentation than early stages. While the phenological stage effect reflects morphological changes in the plant structure, such as leaves, pods, stalks, and their chemical compositions [8] [23], the effect of molasses could be related to either a reduction in moisture or a greater concentration of substrate for silage fermentation [4] [6]. Although both DM and WSC concentrations are crucial for obtaining an efficient silage fermentation [5], our findings suggest these were not limiting factors to produce a high ruminal degradable WSS at R7 stage. However, concentration of WSC was not measured in the current study and our speculation throughout this section should be considered cautiously. Greater DM increments in early phenological stages $(17.2 \%, 15.7 \%$, and $7.8 \%$ respectively to R5, R6, and R7) associated with the increase of $28.0 \%, 14.0 \%$, or $13.7 \%$ in fraction A of DM at R5, R6, and R7, respectively, due to the addition of molasses suggests the additive was effective at increasing WSC concentration [24]. 

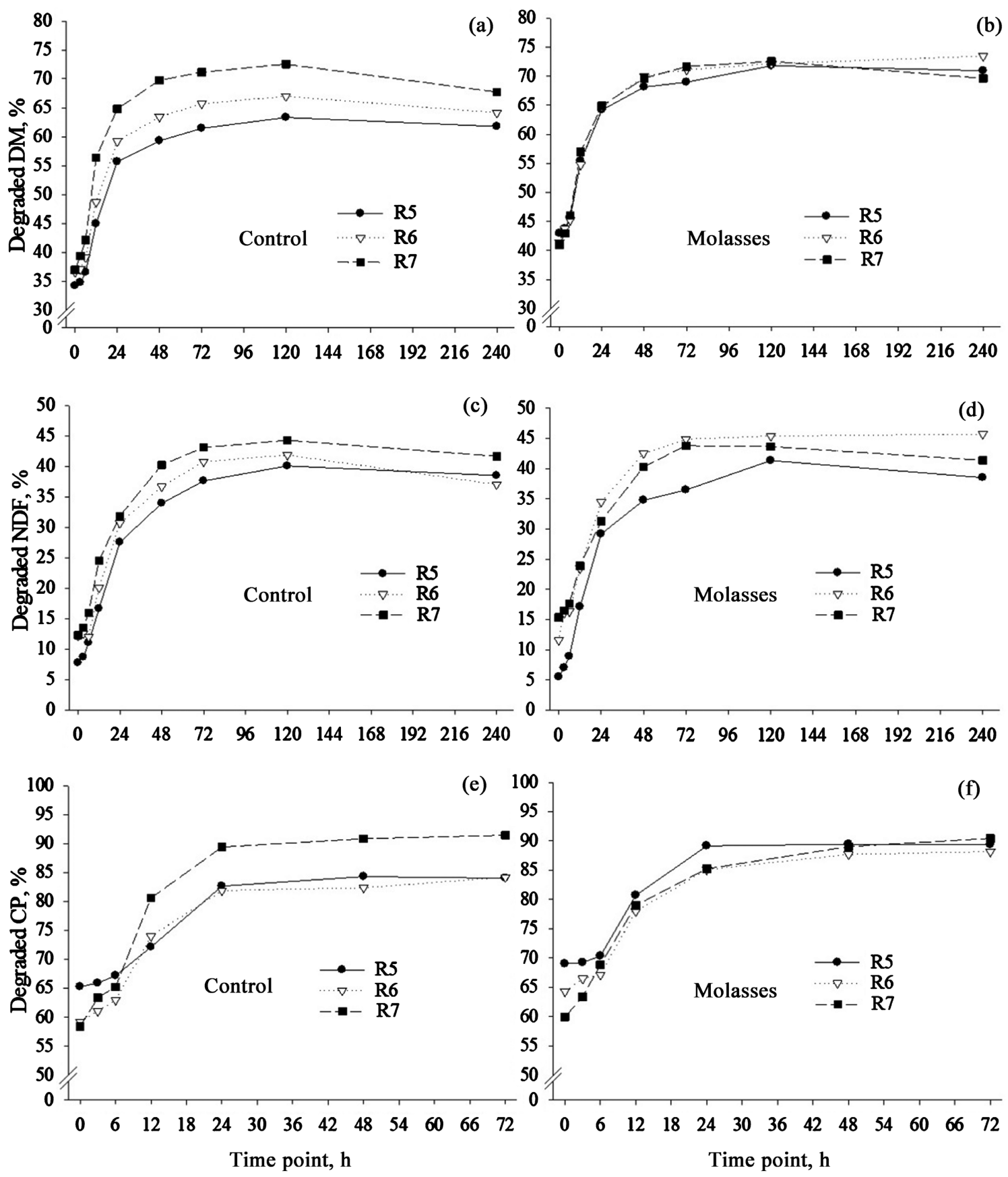

Figure 1. Degraded DM, NDF, and CP of soybean silage without additive ((a), (c), and (e)) or treated with $40 \mathrm{~g} / \mathrm{kg}$ DM of molasses ((b), (d), and (f)) harvested at R5 ( --$)$, R6 $(\cdots \nabla \cdots)$, and R7 ( - ) at each in situ incubation time point $(\mathrm{h})$.

Additionally, fraction C of DM was decreased in molasses-treated silages at R5 and R6 indicating a dilution effect on indigestible compounds by supplying greater nutrient availability [4]. Changes in ruminal DM and nutrient kinetic parameters related to the chemical composition of the forage source have been reported previously [25] [26]. Furthermore, NDF degradation is closely related to DM disappearance. 
At later phenological stages, there is a greater proportion of pods than stalk in soybean plants [8] [23], thereby increasing the proportion of more digestible plant compounds [8] [9]. Prior studies reported an increase in NDF and CP ruminal degradability of WSS when phenological stage progressed from R4 up to R6 [8]. In contrast, a decrease in WSS DM and CP ruminal degradability was reported at R7 in comparison to R6 [9]. In the present study, while the ERD of DM and CP were greater at R5 and R6 in molasses-treated silages, ERD of NDF has increased both with later phenological stage or the addition of molasses.

Greater solubility and rate of degradation of sugars brought into the silage by the addition of molasses are responsible for accelerating bacterial attachment and hence increase the CP soluble fraction regardless of phenological stage [4]. On the other hand, the same effect was observed in early phenological stage where the increase in fraction $\mathrm{A}$ of $\mathrm{CP}$ is at least in part due to greater $\mathrm{NH}_{3}-\mathrm{N}$ commonly found in high-moisture legume silage $(<300 \mathrm{~g} / \mathrm{kg} \mathrm{DM})$ [27]. It is worth to highlight, that although $\mathrm{NH}_{3}-\mathrm{N}$ averages were slightly lower than expected [27], the pattern throughout the treatments are coherent, reflecting the effects of phenological stages and molasses on fermentation profile properly. While greater levels of fraction A of CP improve rumen degradable protein to the microbial population in the rumen as percentage of non-protein nitrogen, fraction C contains proteins associated with lignin [28] that reduce enzymatic access, and portions of fraction B of CP show little, or no input. Thus, we speculate that diets formulated to ruminants containing WSS ensiled in early phenological stage (R5 and R6) or treated with molasses at ensiling require greater concentrations of ruminal degradable carbohydrates source to optimize animal performance [29].

Although high-moisture legume silages, such as R5 and R6 in the present study, are more susceptible to an extensive linkage of $\mathrm{CP}$ to cell wall components [30], no treatment effects on fraction C of CP were observed. However, the ERD of CP increased at R5 and R6 in molasses-treated silages, suggesting changes in the chemical composition of whole-plant soybean with later phenological stages [8] [23] and a shift of the CP fractions from rapidly to slowly degradable with greater $k_{d}$, and lower neutral detergent insoluble nitrogen concentration [31] [32].

The UNDF decreased and ERD of NDF increased in WSS harvested at later phenological stages. This was related to the greater proportion of pods, and hence of the NDF digestible fraction, in later phenological stages. This finding is essential, as the morphological distribution of lignin in legumes is challenging to rumen microbial access and degradation of cell walls [33]. Increasing the potentially digestible fraction would allow for a greater inclusion of WSS in ruminant diets. Alternatively, it would allow ruminants to maintain similar performance when fed diets balanced to have similar NDF concentration [3]. Both, phenological stage and the addition of molasses are practices that can be easily implemented by producers to manipulate the degradation of structural polysaccha- 
rides and thus, change the NDF pool size, potentially improving animal performance [34].

\section{Conclusion}

Although a positive effect of phenological stage on ruminal degradation parameters of DM, CP, and NDF was observed, the magnitude of these effects was less pronounced in molasses-treated silages. Thus, despite the more pronounced effects of molasses that were observed in R5 and R6, its inclusion in whole-plant soybean silage is beneficial regardless of phenological stage. Changes in the proportion of digestible nutrients either by later phenological stage or the addition of molasses are powerful strategies to improve ruminal DM and nutrient degradation of whole-plant soybean silage.

\section{Acknowledgements}

The authors acknowledge the University of São Paulo (Pirassununga, Brazil), Dairy Cattle Research Laboratory of the University of São Paulo (Pirassununga, Brazil), and University of Florida (Gainesville, USA) for providing infrastructure, staff, land, and animal support. Lucas Ghedin Ghizzi expresses his acknowledgement to São Paulo Research Foundation (FAPESP, São Paulo, Brazil; grant $\#$ 2019/02653-8) for providing his scholarship.

\section{Conflicts of Interest}

The authors declare no conflicts of interest regarding the publication of this paper.

\section{References}

[1] Baghdadi, A., Halim, R.A., Radziah, O., Martini, M.Y. and Ebrahimi, M. (2016) Fermentative Characteristics and Nutritive Value of Corn Silage Intercropped with Soybean under Different Crop Combination Ratios. The Journal of Animal \& Plant Sciences, 26, 1710-1717.

[2] Parra, C.S., Bolson, D.C., Jacovaci, F.A., Nussio, L.G., Jobim, C.C. and Daniel, J.L.P. (2019) Influence of Soybean-Crop Proportion on the Conservation of $\mathrm{Ma}$ ize-Soybean Bi-Crop Silage. Animal Feed Science and Technology, 257, Article ID 114295. https://doi.org/10.1016/j.anifeedsci.2019.114295

[3] Ghizzi, L.G., Del Valle, T.A., Zilio, E.M.C., Sakamoto, L.Y., Marques, J.A., Dias, M.S.S., Nunes, A.T., Gheller, L.S., Silva, T.B.P., Grigoletto, N.T.S., Takiya, C.S., Silva, G.G. and Rennó, F.P. (2020) Partial Replacement of Corn Silage with Soybean Silage on Nutrient Digestibility, Ruminal Fermentation, and Milk Fatty Acid Profile on Dairy Cows. Animal Feed Science and Technology, 266, Article ID: 114526. https://doi.org/10.1016/j.anifeedsci.2020.114526

[4] Ni, K., Wang, F., Zhu, B., Yang, J., Zhou, G., Pan, Y., Tao, Y. and Zhong, J. (2017) Effects of Lactic Acid Bacteria and Molasses Additives on the Microbial Community and Fermentation Quality of Soybean Silage. Bioresource Technolonogy, 238, 706-715. https://doi.org/10.1016/j.biortech.2017.04.055

[5] McDonald, P., Henderson, N. and Herson, S. (1991) The Biochemistry of Silage. 
2nd Edition, Chalcombe, Marlow.

[6] Tobía, C., Villalobos, E., Rojas, A., Soto, H. and Moore, K.J. (2008) Nutritional Value of Soybean (Glycine max L. Merr.) Silage Fermented with Molasses and Inoculated with Lactbacillus brevis 3. Livestock Research for Rural Development, 20, Article No. 106.

[7] Rigueira, J.P.S., Pereira, O.G., Valadares Filho, S.C., Ribeiro, K.G., Garcia, R. and Cezáreo, A.S. (2015) Soybean Silage in the Diet for Beef Cattle. Acta Scientiarum, 37, 61-65. https://doi.org/10.4025/actascianimsci.v37i1.25182

[8] Spanghero, M., Zanfi, C., Signor, M., Davanzo, D., Volpe, V. and Venerus, S. (2015) Effects of Plant Vegetative Stage and Field Drying Time on Chemical Composition and In Vitro Ruminal Degradation of Forage Soybean Silage. Animal Feed Science and Technology, 200,102-106. https://doi.org/10.1016/j.anifeedsci.2014.11.006

[9] Kawamoto, H., Touno, E., Uchino, H. and Uozumi, S. (2013) Comparison of Fermentation Quality and Ruminal Degradability between Two Different Harvest Timings of Forage Soybean (Glycine $\max$ (L.) Merr.) Ensiled with the Corn-Silage System. Grassland Science, 59, 120-123. https://doi.org/10.1111/grs.12015

[10] Dias, J.F., Jobim, C.C., Filho, J.L.S., Junior, V.H.B., Poppi, E.C. and Santello, G.A. (2010) Chemical Composition and Dry Matter Total Losses of Soybean Plant Silage. Acta Scientiarum. Animal Sciences, 32, 19-26.

[11] Ghizzi, L.G. (2020) Whole-Plant Soybean Silage Management and Its Use in Dairy Cow's Diet. PhD Thesis, University of São Paulo, Pirassununga.

[12] Fehr, W.R. and Caviness, C.E. (1977) Stage of Soybean Development. Special Report No. 80. Co-Operative Extension Service, Iowa State University, Ames.

[13] AOAC International (2012) Official Methods of Analysis. AOAC International, 19th Edition, AOAC International, Arlington.

[14] AOAC International (2000) Official Methods of Analysis. AOAC International, 17th Edition, AOAC International, Arlington.

[15] Van Soest, P.J., Robertson, J.B. and Lewis, B.A. (1991) Methods for Dietary Fiber, Neutral Detergent Fiber, Non-Starch Polysaccharides in Relation to Animal Nutrition. Journal of Dairy Science, 74, 3583-3597. https://doi.org/10.3168/jds.S0022-0302(91)78551-2

[16] Undersander, D., Mertens, D.R. and Thiex, N. (1993) Forage Analyses Procedures. National Forage Testing Association, Omaha.

[17] Hall, M.B. (2000) Calculation of Non-Structural Carbohydrate Content of Feeds That Contain Non-Protein Nitrogen. Bulletin No. 339, University of Florida, Gainesville, A-25.

[18] Playne, M.J. and McDonald, P. (1966) The Buffering Constituents of Herbage and of Silage. Journal of the Science Food and Agriculture 17, 264-268. https://doi.org/10.1002/jsfa.2740170609

[19] Broderick, G.A. and Kang, J.H. (1980) Automated Simultaneous Determination of Ammonia and Total Amino Acids in Ruminal Fluid in Vitro Media. Journal of Dairy Science, 63, 64-75. https://doi.org/10.3168/jds.S0022-0302(80)82888-8

[20] Pryce, J.D.A. (1969) Modification of the Barker-Summerson Method for the Determination of Latic Acid. Analyst, 94, 1151-1152.

https://doi.org/10.1039/an9699401151

[21] Ørskov, E.R. and McDonald, I. (1979) The Estimation of Protein Degradability in the Rumen from Incubation Measurements Weighted According to Rate of Passage. 
The Journal of Agricultural Science. 92, 499-503. https://doi.org/10.1017/S0021859600063048

[22] Kenward, M.G. and Roger, J.H. (1997) Small Sample Inference for Fixed Effects from Restricted Maximum Likelihood. Biometrics, 53, 983-997. https://doi.org/10.2307/2533558

[23] Zhai, G., Shen, Y., Zhai, Y., Liu, X. and Jiag, H. (2013) Forage Yield Performance and Nutritive Value of Selected Wild Soybean Ecotypes. Canadian Journal of Plant Science, 88, 465-472. https://doi.org/10.4141/CJPS06005

[24] Sniffen, C.J., O’connor, J.D., Van Soest, P.J., Fox, D.G. and Russel, J.B. (1992) A Net Carbohydrate and Protein System for Evaluating Cattle Diets: II. Carbohydrate and Protein Availability. Journal of Animal Science, 70, 3562-3577. https://doi.org/10.2527/1992.70113562x

[25] Varga, G.A. and Hoover, W.H. (1983) Rate and Extent of Neutral Detergent Fiber Degradation of Feedstuffs In Situ. Journal of Dairy Science, 66, 2109-2115. https://doi.org/10.3168/jds.S0022-0302(83)82057-8

[26] Bruno-Soares, A.M., Abreu, J.M.F., Guedes, C.V.M. and Dias-da-Silva, A.A. (2000) Chemical Composition, DM and NDF Degradation Kinetics in Rumen of Seven Legume Straws. Animal Feed Science and Technology, 83, 75-80. https://doi.org/10.1016/S0377-8401(99)00113-3

[27] Kung Jr, L., Shaver, R.D., Grant, R.J. and Schmidt, R.J. (2018) Silage Review: Interpretation of Chemical, Microbial, and Organoleptic Components of Silages. Journal of Dairy Science, 101, 4020-4033. https://doi.org/10.3168/jds.2017-13909

[28] Russell, J.B., O'Connor, J.D., Fox, D.G., Van Soest, P.J. and Sniffen, C.J. (1992) A Net Carbohydrate and Protein System for Evaluating Cattle Diets: I. Ruminal Fermentation. Journal of Animal Science, 70, 3551-3561. https://doi.org/10.2527/1992.70113551x

[29] National Research Council (2001) Nutrient Requirements of Dairy Cattle. 7th Revised Edition, National Academies Press, Washington DC.

[30] Higgs, R.J., Chase, L.E., Ross, D.A. and Van Amburgh, M.E. (2015) Updating the CNCPS Feed Library and Analyzing Model Sensitivity to Feed Inputs. Journal of Dairy Science, 98, 6340-6360. https://doi.org/10.3168/jds.2015-9379

[31] Janicki, F.J. and Stallings, C.C. (1988) Degradation of Crude Protein in forages Determined by In Vitro and In Situ Procedures. Journal of Dairy Science, 71, 2440-2448. https://doi.org/10.3168/jds.S0022-0302(88)79829-X

[32] Mertens, D.R. (2016) Measuring and Using uNDF to Improve Dairy Nutrition. Southwest Nutrition Conference, Tempe, 17-19 February 2016, 12-19.

[33] Wilson, J.R. and Kennedy, P.M. (1996) Plant and Animal Constraints to Voluntary Feed Intake Associated with Fibre Characteristics and Particle Breakdown and Passage in Ruminants. Australian Journal of Agricultural Research, 47, 199-225. https://doi.org/10.1071/AR9960199

[34] Jung, H.G. and Allen, M.S. (1995) Characteristics of Plant Cell Walls Affecting Intake and Digestibility of Forages by Ruminants. Journal of Animal Science, 73, 2774-2790. https://doi.org/10.2527/1995.7392774x 